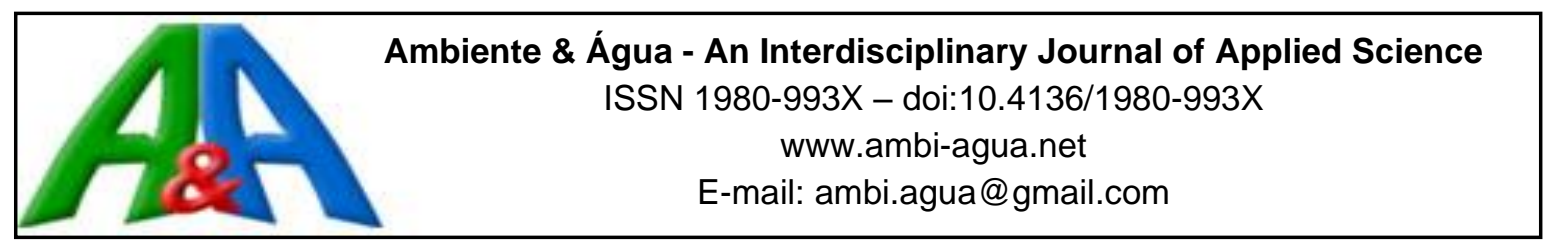

\title{
Performance of colored cotton under irrigation water salinity and organic matter dosages
}

\author{
ARTICLES doi:10.4136/ambi-agua.2369
}

Received: 17 Jan. 2019; Accepted: 06 Aug. 2019

\author{
Patrícia dos Santos Nascimento ${ }^{1}$; Lucylia Suzart Alves ${ }^{2 *}$; \\ Vital Pedro da Silva Paz ${ }^{3}$ (D)
}

\begin{abstract}
${ }^{1}$ Departamento de Tecnologia (DTEC), Universidade Estadual de Feira de Santana (UEFS), Avenida
Transnordestina, S/N, CEP 44036-900, Feira de Santana, BA, Brazil. E-mail: patysnasc@gmail.com ${ }^{2}$ Programa de Pós-Graduação em Engenharia Civil e Ambiental (PPGECEA), Universidade Estadual de Feira de Santana (UEFS), Avenida Transnordestina, S/N, CEP 44036-900, Feira de Santana, BA, Brazil.

${ }^{3}$ Núcleo de Engenharia de Água e Solo (NEAS), Universidade Federal do Recôncavo da Bahia (UFRB), Rua Rui Barbosa, n 710, CEP 44380-000, Cruz das Almas, BA, Brazil. E-mail: vpspaz@gmail.com *Corresponding author. E-mail: lusuzart85@yahoo.com.br
\end{abstract}

\begin{abstract}
This work evaluated the development of colored cotton submitted to irrigation water of different salinity levels and organic matter doses from tanned manure. The experimental design was completely randomized in a $4 \times 4$ factorial scheme with 3 replications, totaling 48 experimental plots. The factors studied were 4 doses of organic matter (1, 4, 7 and 10\%) and four levels of irrigation water salinity $\left(0.26 ; 1,2\right.$ and $\left.4 \mathrm{dS} \mathrm{m}^{-1}\right)$. The variables analyzed were plant height, stem diameter, number of leaves, number of fruits and fresh shoot mass. Significant effect of organic matter was observed on all studied variables, with a positive response on the increase of all variables as a function of increasing doses of organic matter. The isolated effect of salinity was significant for all parameters evaluated, except for the number of leaves, with significant reductions of $6.03 ; 3.27 ; 5.23 ; 6.94 \%$ in the parameters: plant height, stem diameter, number of fruits and shoot fresh weight respectively, for each unit increase of irrigation water salinity. The interaction between the variation sources studied had a significant effect only for fresh shoot mass, where the highest average for this parameter was observed at $10 \%$ organic matter dosage at irrigation water salinity level of $1.0 \mathrm{dS} \mathrm{m}$.
\end{abstract}

Keywords: fertilization, Gossypium hirsutum, saline stress.

\section{Desempenho do algodoeiro colorido sob salinidades da água de irrigação e dosagens de matéria orgânica}

\section{RESUMO}

Este trabalho foi realizado com o objetivo de avaliar o desenvolvimento do algodoeiro colorido, submetido a diferentes níveis de salinidade da água de irrigação e doses de matéria orgânica proveniente de esterco bovino curtido. $\mathrm{O}$ delineamento experimental utilizado foi inteiramente casualizado em esquema fatorial 4 x 4, com 3 repetições, totalizando 48 parcelas experimentais. Os fatores estudados foram 4 doses de matéria orgânica $(1 ; 4 ; 7$ e $10 \%)$ e quatro níveis de salinidade da água de irrigação $\left(0,26 ; 1 ; 2\right.$ e $\left.4 \mathrm{dS} \mathrm{m}^{-1}\right)$. As variáveis analisadas foram: altura da planta, diâmetro do caule, número de folhas, número de frutos e massa fresca da parte

This is an Open Access article distributed under the terms of the Creative Commons Attribution License, which permits unrestricted use, distribution, and reproduction in any medium, provided the original work is properly cited. 
aérea. Notou-se efeito significativo da matéria orgânica sobre todas as variáveis estudadas, com uma resposta positiva no aumento de todas as variáveis em função das doses crescentes de matéria orgânica. $\mathrm{O}$ efeito isolado da salinidade foi significativo para todos os parâmetros avaliados, com exceção para o número de folhas, sendo verificadas reduções significativas de 6,$03 ; 3,27 ; 5,23 ; 6,94 \%$ nos parâmetros: altura de plantas, diâmetro do caule, número de frutos e massa fresca da parte aérea respectivamente, para cada acréscimo unitário da salinidade da água de irrigação. A interação entre as fontes de variação estudadas ocasionou efeito significativo somente para a massa fresca da parte aérea, onde a maior média para esse parâmetro foi observada na dosagem de $10 \%$ de matéria orgânica no nível de salinidade da água de irrigação de $1,0 \mathrm{dS} \mathrm{m}^{-1}$.

Palavras-chave: adubação, estresse salino, Gossypium hirsutum.

\section{INTRODUCTION}

Herbaceous cotton (Gossypium hirsutum L.) is one of the main crops in Brazil (Costa et $a l ., 2008)$. Its production is concentrated in the midwest and northeast, where cotton is a socio economically important crop, cultivated under rainfed or irrigated conditions (Carvalho et al., 2015).

Cotton cultivation with the naturally colored fiber has been gaining prominence in the national scenario, especially due to the environmentally correct character of its cultivation, which dispenses with the need for artificial dyeing. In this context, many studies have been developed to better understand the productive aspects and conditions of culture (Souza et al., 2018; Pedro et al., 2016).

Thus, cotton farming in the northeast region has been highlighted as one of the agricultural activities of great value for Brazilian agribusiness, as well as being a means of fixing man in the countryside and strengthening family agriculture. However, research is needed to better manage the crop and improve productive efficiency.

Salinity is one of the main environmental factors that limit plant growth and productivity. This limitation occurs because, under saline conditions, there is a reduction in the availability of water to the plants, due to the decrease in the osmotic potential of the soil solution; Thus, the plant tends to expend more energy to absorb water and nutrients (Leonardo et al., 2003).

The high concentrations of salts in soil and water, besides reducing soil water potential, are reflected in the inhibition and unevenness of growth, decline in production capacity and quality of the products obtained from plants grown due to the direct effects on the osmotic potential, nutritional imbalance and toxic effect of ions, especially chloride and sodium (Lacerda et al., 2003).

Cotton is considered a moderately tolerant crop to the presence of salts in the soil (Taiz and Zeiger, 2009). However, the authors point out that, despite this tolerance, the culture can suffer substantial reductions in its growth, production and quality of the product obtained when exposed to the saline stress condition (Oliveira et al., 2008). Thus, one aspect that has been studied is the use of fertilizers in the plants under salinity conditions, demonstrating that the use of biofertilizers in saline environments may reduce the effects of salinity on plant growth (Dias et al., 2016; Lima et al., 2014; Santos et al., 2014).

This work evaluated the development of the colored cotton submitted to irrigation water of different salinity levels and organic matter doses.

\section{MATERIALS AND METHODS}

The experiment was conducted in a greenhouse belonging to the Postgraduate Program in Agricultural Engineering of the Federal University of Recôncavo da Bahia (PPGEA / UFRB),

Rev. Ambient. Água vol. 14 n. 5, e2369 - Taubaté 2019 
in the municipality of Cruz das Almas, BA, at 1240' $19^{\prime}$ latitude south, $39^{\circ} 06$ ' $23^{\prime}$ ' west longitude and average altitude of $220 \mathrm{~m}$.

Seeds of the cultivar BRS Topázio, of brown color fiber, were used. The experimental unit was represented by a plastic vessel with a capacity of $20 \mathrm{~L}$ of soil, which was filled with $0.5 \mathrm{~kg}$ of gravel $\left(\mathrm{N}^{\circ} 0\right)$, which covered the base of the vessel, followed by a bidim blanket cut in the shape of the base of the vessel, in the sequence was added $18 \mathrm{~kg}$ of soil from the municipality of Cruz das Almas, BA. Each of the vessels contained a hole in the base, which allowed the soil to drain.

The experimental design was completely randomized in a $4 \times 4$ factorial scheme, with three replications, totaling 48 experimental plots. The treatments were the result of the combination of four levels of irrigation water salinity: water supply ( 0.26 - control $) ; 1,2$ and 4 $\mathrm{dS} \mathrm{m}{ }^{-1}$ with four doses of organic matter: $1,4,7$ and $10 \%$ of the weight of the soil contained in the vessel. The organic matter used in this experimental conduction was cattle manure, being the only nutritional source for the development of the crop during the cycle. The manure was inserted in the vessels in the assembly phase of the same as a function of the proposed treatments. The salinity of the irrigation water was obtained by adding sodium chloride $(\mathrm{NaCl})$ to the local water supply $\left(0.26 \mathrm{dS} \mathrm{m}^{-1}\right)$, in order to obtain water with different levels of salinity. Irrigation management was carried out based on the tensiometry, associated to the information of the characteristic curve of the soil in question. A tensiometer was installed at a depth of 15 $\mathrm{cm}$ in each of the treatments and replicates tested, the respective irrigation slides were calculated based on the matric potential of the soil, so as to adjust soil moisture to the field capacity, such replacement was manually performed as needed. The application of salinity treatments occurred at 8 days after sowing and lasted until the end of the crop cycle (114 days after sowing) in the different treatments proposed.

The following biometric parameters of the cotton plant were measured during the development cycle: plant height (AP), stem diameter (DC), number of leaves (NFOL), number of fruits (NFRU) and at the end of the cycle the mass was evaluated (MFPA) in order to verify the effect of the treatments tested.

The results were submitted to analysis of variance by the $\mathrm{F}$ test and regression, which were adjusted to linear and polynomial models of first and second degree. For this, the Tukey test was applied at a 5\% probability level. For the significant interactions, the analysis of variance was performed considering the factors salinity levels and organic matter levels.

\section{RESULTS AND DISCUSSION}

The results of the analysis of variance shown in Table 1 show that there was a significant effect of the treatments tested for the parameters: plant height (AP), stem diameter (DC), fruit number (NFRU) and fresh shoot mass MFPA); only the number of leaves (NFOL) did not show a significant effect as a function of irrigation water salinity. In the interaction between the sources of variation, the increases in organic matter dosages together with irrigation water salinity levels interfered significantly $(\mathrm{p}<0,01)$ in fresh shoot mass. In a study by Souza et al. (2018) in the cotton crop, only the stem diameter parameter presented significant interaction when evaluating salinity levels and organic matter doses.

The height of plants, stem diameter, fruit number and number of leaves of the cotton was not influenced by the interaction between salinity and organic matter doses, corroborating the results observed by Santos et al. (2014) and Nobre et al. (2010) when evaluating irrigation water salinity levels and nitrogen fertilization on the growth of colored cotton and sunflower plants, respectively. 
Table 1. Summary of analysis of variance for plant height (AP), stem diameter (DC), leaf number (NFOL), number of fruits (NFRU) and fresh shoot mass (MFPA) of the colored cotton submitted to doses of organic matter and increasing levels of salinity of irrigation water.

\begin{tabular}{lcccccc}
\hline \multirow{2}{*}{ Sources of Variation } & \multirow{2}{*}{ GL } & \multicolumn{5}{c}{ Average Squares } \\
\cline { 2 - 7 } & & AP & DC & NFOL & NFRU & MFPA \\
\hline Organic Matter (MO) & 3 & $5288.22 * *$ & $25.45^{* *}$ & $1342.40^{* *}$ & $302.02^{* *}$ & $2878.23^{* *}$ \\
Salinity (S) & 3 & $1737.50^{* *}$ & $4.70^{* *}$ & $46.18 \mathrm{~ns}$ & $16.52^{*}$ & $1246.48^{* *}$ \\
MO x S & 9 & $121.16 \mathrm{~ns}$ & $0.79 \mathrm{~ns}$ & $66.15 \mathrm{~ns}$ & $2.52 \mathrm{~ns}$ & $374.19^{* *}$ \\
Error & 32 & 158.37 & 0.55 & 54.29 & 5,43 & 111.55 \\
CV $(\%)$ & & 11.83 & 7.29 & 19.44 & 19,95 & 22.25 \\
\hline
\end{tabular}

**** represent significant effect at 0,01 e 0,05 probability; ns - not significant by $\mathrm{F}$ test; GL - degree of freedom; CV - coefficient of variation

By analyzing the isolated effects of the sources of variation, it is observed that, in general, the increase of the organic matter doses stimulated the cotton growth (Figures 1A, B, C, D and E). Thus, the highest values of AP, DC, NFOL, NFRU and MFPA, respectively, were found in the highest dosages of organic matter, respectively. These results demonstrate the contribution of nitrogen to the physiological metabolism of plants and may be directly related to the formation of proteins, which are essential for the plant to express its agronomic potential (Nascimento et al., 2017a).

The organic matter yields from $4 \%$ increased plant height, such biometric expressiveness was favored by fertilizer supply, which may have contributed to soil fertility and structuring (Costa et al., 2008). Pereira et al. (2012), when evaluating the influence of cattle manure doses on the agronomic characteristics of the herbaceous cotton cv. BRS Rubi, observed a linear increase in plant height. The trend of growth as a function of the applied organic matter was also verified for the parameter diameter of the stem, similar to that observed by Dias et al. (2016) in cotton fiber cultivation.

Regarding the number of leaves and fruits, the evolution was similar to the growth of the plants in height and diameter of the stem, it is observed that the organic matter doses from $4 \%$ provided increases in these variables with the emission of leaves and fruits by the cotton plants. For Souza et al. (2018) the addition of organic matter promotes increased growth and cotton production.

The application of the organic matter doses promoted an increase of $33.95 \mathrm{~g}$ of the fresh mass of the aerial part with the dose of $10 \%$ of organic matter, a value greater than twice that found in the control treatment $(26.52 \mathrm{~g})$. This behavior is justified by the addition of nitrogen and its influence in most physiological processes that occur in plants, such as protein synthesis and photosynthesis, defining it as the nutrient that most limits the production of plant biomass (Yong et al., 2010).

As shown in Figures $2 \mathrm{~A}, \mathrm{~B}, \mathrm{C}$ and D, the increase in electrical conductivity of irrigation water from 0.26 to $4.0 \mathrm{dS} \mathrm{m}^{-1}$ provided a significant reduction in plant height (AP), diameter of stem (DC), number of fruits (NFRU) and fresh shoot mass (MFPA), with reductions of 6.03; $3.27 ; 5.23 ; 6.94 \%$ respectively, for each unit increase in the salinity of the irrigation water.

The increase in salinity of irrigation water promoted a reduction in water availability due to the high concentration of salts in the root zone, which may have caused a reduction in the plant metabolism, evidenced by the reduction of height of plants, stem diameter, number of fruits and fresh mass of the aerial part. These results corroborate those observed by Oliveira $e t$ al. (2008) and Santos et al. (2014), who observed that, when evaluating saline water levels in cotton cultivars, the fresh phytomass presented linear declining behavior. 
A

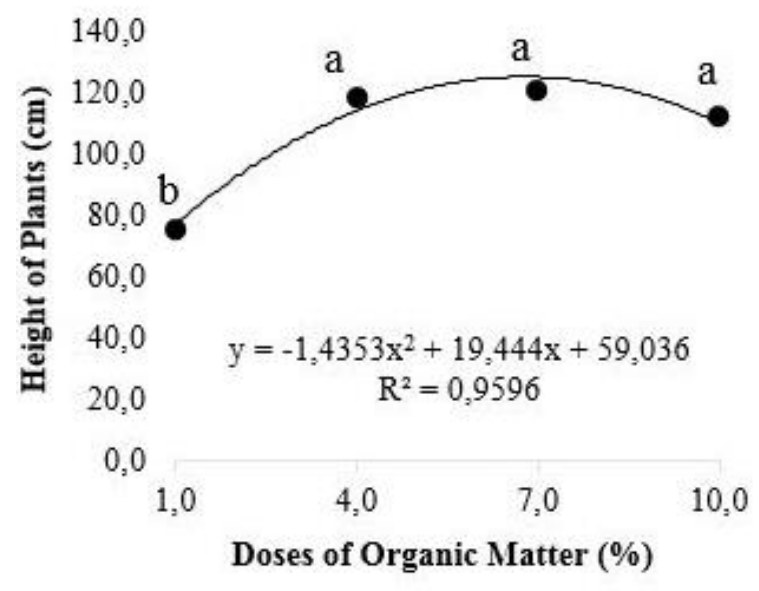

C

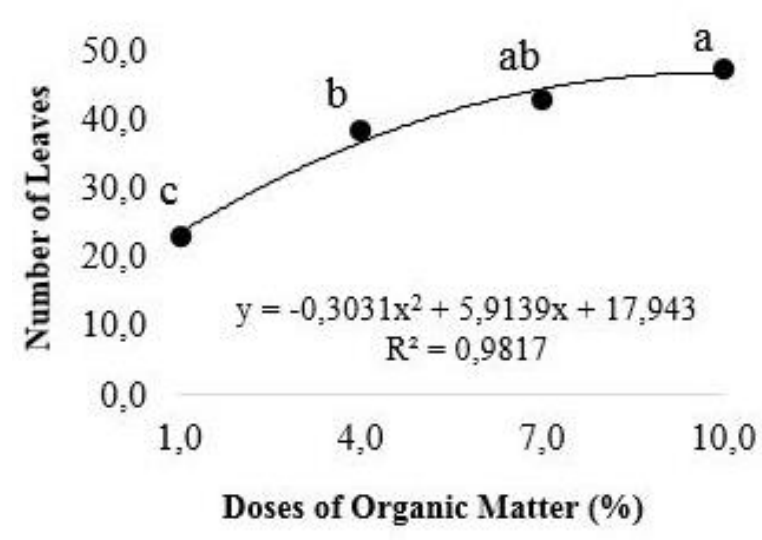

B

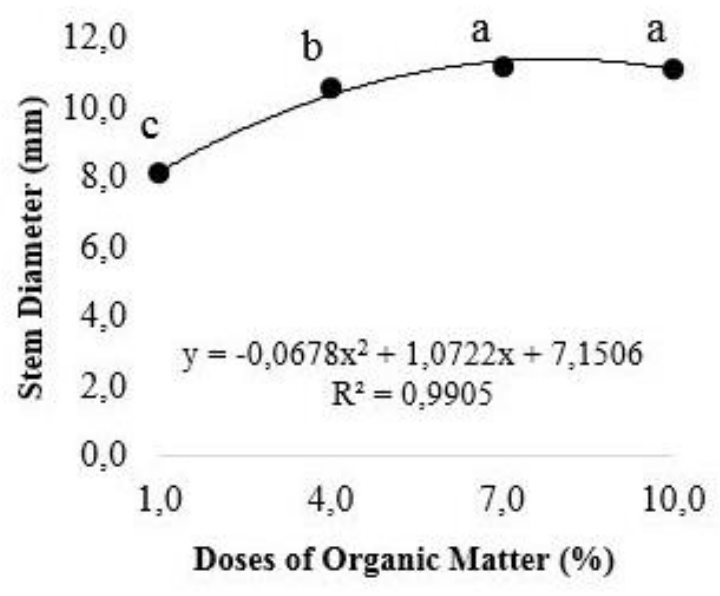

D

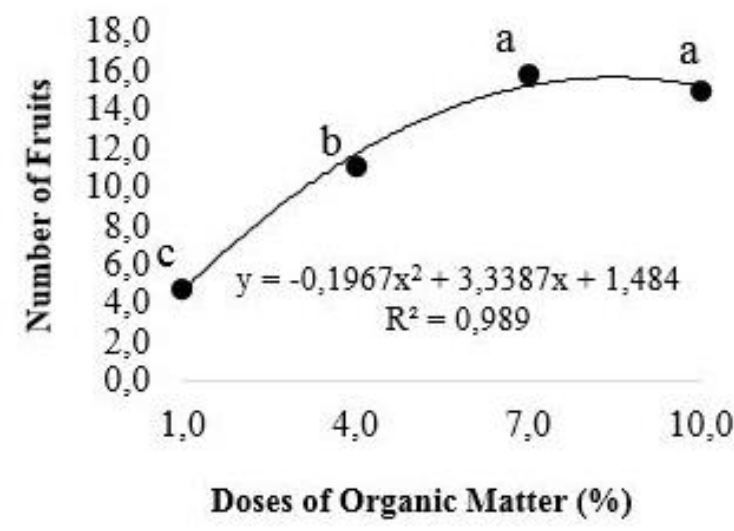

$\mathbf{E}$

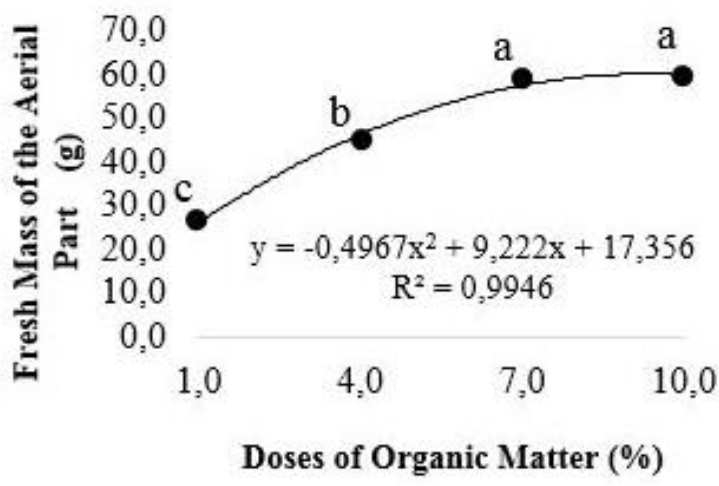

Figure 1. Height of Plants (A), Stem Diameter (B), Number of Leaves (C), Number of Fruits (D) and Fresh Mass of the Aerial Part (E) as a function of organic matter doses; Means followed by different lower case letters differ statistically from each other by the 0,05 probability Tukey test.

The reduction in the expression of biometric characteristics with the increase of irrigation water salinity levels was also observed by Nascimento et al. (2017b) in okra cultivation, Araújo et al. (2016) in melon cultivation, Nobre et al. (2014) in castor bean cultivation and Sá et al. (2013) in papaya cultivation.

According to the F test, no significant difference was observed for the number of leaves 
observed in the salinity treatment; such results agree with those observed by Ferreira et al. (2012) and Nascimento et al. (2017b) when studying the effect of salinity on the production of okra grains.

For plant height and stem diameter, treatments with salinity levels of 0.26 and $1.00 \mathrm{dS} \mathrm{m}{ }^{-1}$ did not differ statistically, presenting higher results than treatments with salinity levels 2 and 4 $\mathrm{dS} \mathrm{m} \mathrm{m}^{-1}$.

A

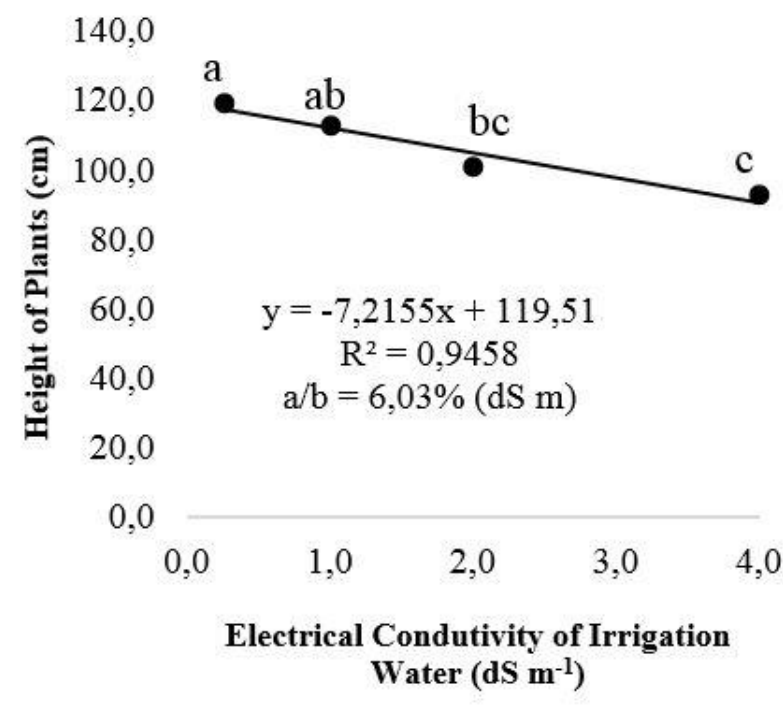

C

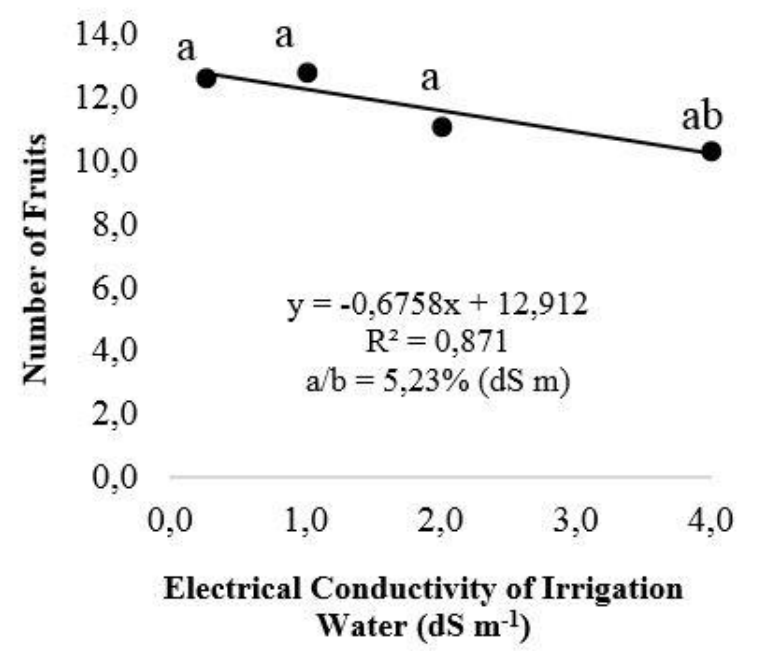

B

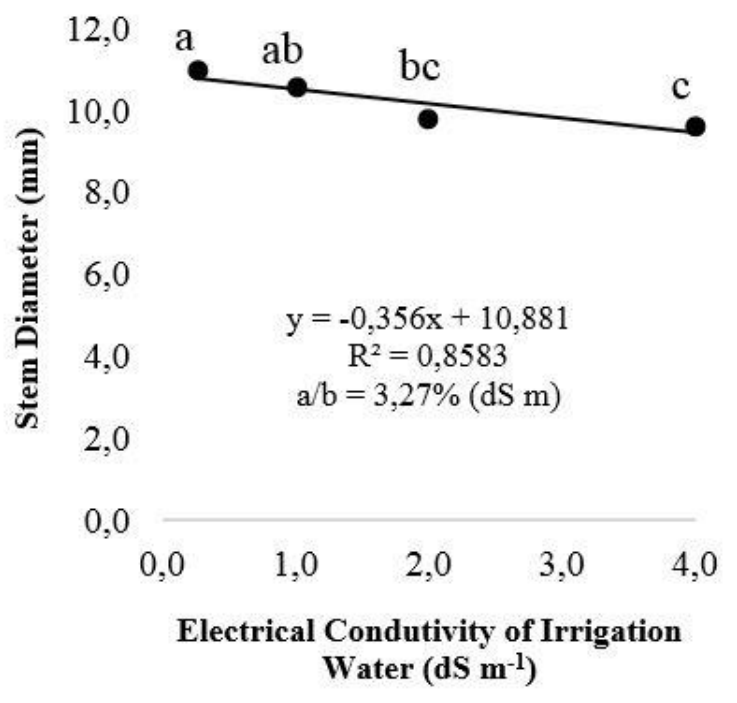

D

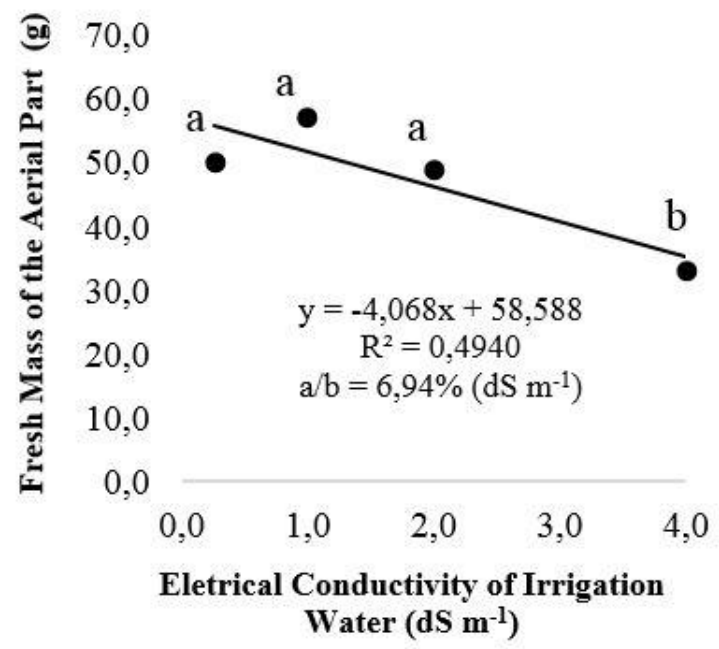

Figure 2. Height of Plants (A), Stem Diameter (B), Number of Fruits (C) and Fresh Mass of the Aerial Part (D) as a function of salinity of irrigation water; Means followed by different lower case letters differ statistically from each other by the 0.05 probability Tukey test.

From the significance verified for the parameter shoot fresh mass (MFPA) in the interaction between organic matter doses and salinity levels, the organic matter doses were split within the irrigation water salinity levels, verifying that the highest MFPA averages were obtained at a $10 \%$ dose within the $1.0 \mathrm{dS} \mathrm{m}^{-1}$ salinity level (Table 2). 
Table 2. Interaction split means (Organic Matter x Salinity) for shoot fresh matter (MFPA).

\begin{tabular}{|c|c|c|c|c|}
\hline \multicolumn{5}{|c|}{ Medium } \\
\hline \multirow{2}{*}{ Variation source } & \multicolumn{4}{|c|}{ Salinity } \\
\hline & $0,26 \mathrm{dS} \mathrm{m}^{-1}$ & $1,0 \mathrm{dS} \mathrm{m}^{-1}$ & $2,0 \mathrm{dS} \mathrm{m}^{-1}$ & $4,0 \mathrm{dS} \mathrm{m}^{-1}$ \\
\hline \multicolumn{5}{|l|}{ Organic Matter } \\
\hline $1 \%$ & $21.94 \mathrm{bA}$ & $31.37 \mathrm{bA}$ & $31.31 \mathrm{bA}$ & $21.46 \mathrm{bA}$ \\
\hline $4 \%$ & $54.30 \mathrm{aA}$ & $45.89 \mathrm{bA}$ & 39.88 bA & $39.86 \mathrm{abA}$ \\
\hline $7 \%$ & $66.57 \mathrm{aAB}$ & $69.34 \mathrm{aA}$ & $54.38 \mathrm{abAB}$ & $45.27 \mathrm{aB}$ \\
\hline $10 \%$ & $58.46 \mathrm{aB}$ & $83.20 \mathrm{aA}$ & $69.80 \mathrm{aAB}$ & $26.43 \mathrm{abC}$ \\
\hline
\end{tabular}

Lower case letters in the columns compare the average dosages of organic matter within the salinity levels of irrigation water; capital letters in the lines compare the average salinity levels of irrigation water within the organic matter dosages by the Tukey test at a 0.05 probability level.

In general, the increase in the organic matter dosage to the same salinity level provides an increase in the average values found for the MFPA parameter, except for the $10 \%$ organic matter dosage at $4.0 \mathrm{dS} \mathrm{m}^{-1}$, salinity presented a reduction in the mean values of the MFPA. It was also observed that there was no significant difference in the $1 \%$ dose of organic matter, regardless of the salinity level tested $\left(0.26-4.0 \mathrm{dS} \mathrm{m}{ }^{-1}\right)$.

Alves et al. (2009), evaluating the interaction of nitrogen fertilization versus water type in brown cotton cultivation, also found significant effect only for biomass.

\section{CONCLUSIONS}

The organic matter doses tested had a significant effect on plant height, stem diameter, number of leaves and fruits and fresh shoot mass.

The increase in salinity levels of irrigation water had a negative influence on the expression of the following biometric characteristics: plant height, stem diameter, number of fruits and fresh shoot mass, with mean decreases of $6.03 ; 3.27 ; 5.23$ and $6.94 \%$, respectively, for each unit increase in the salinity of the irrigation water.

The interaction between the organic matter and the salinity levels were significant for the parameter fresh mass of the aerial part.

\section{REFERENCES}

ALVES, W. W. A.; AZEVEDO, C. A. V.; DANTAS, J. N.; SOUSA, J. T. de.; LIMA, V. L. A. Águas residuárias e nitrogênio: efeito na cultura do algodão marrom. Revista Verde, v.4, n.1, p.16-23, 2009.

ARAÚJO, E. B. G.; SÁ, F. V. da S.; OLIVEIRA, F. A.; SOUTO, L. S.; PAIVA, E. P; SILVA, M. K. do N.; MESQUITA, E. F. de M.; BRITO, M. E. B. Crescimento inicial e tolerância de cultivares de meloeiro à salinidade da água. Revista Ambiente \& Água, v.11, p.462471, 2016. https://dx.doi.org/10.4136/ambi-agua.1726

CARVALHO, L. P.; SALGADO, C. C.; FARIAS, F. J. C.; CARNEIRO, V. Q. Estabilidade e adaptabilidade de genótipos de algodão de fibra colorida quanto aos caracteres de fibra. Ciência Rural, v.45, p.598-605, 2015. http://dx.doi.org/10.1590/0103-8478cr20130237 
COSTA, A. C. P.; MACEDO, F. S.; HONCZAR, G. Algodão. In: Agronegócio brasileiro. São Paulo: Sonopress Gráfica, 2008. p. 24-29.

DIAS, A. S.; NOBRE, R. G.; LIMA, G. S.; GHEYI, H. R.; PINHEIRO, F. W. A. Crescimento e produção de algodoeiro de fibra colorida cultivado em solo salino-sódico e adubação orgânica. Irriga, p.260-273, 2016.

FERREIRA, L. E.; MEDEIROS, J. F. de; SILVA, N. K. C.; LINHARES, P. S. F.; ALVES, R. de C. Salinidade e seu efeito sobre a produção de grãos do quiabeiro Santa Cruz 47. Revista Verde de Agroecologia e Desenvolvimento Sustentável, v.7, n.4, p.108-113, 2012 .

LACERDA, C. F.; CAMBRAIA, J.; OlIVA, M. A.; RUIZ, H. A.; PRISCO, J. T. Solute accumulation and distribution shoot and leaf development in two sorghum genotypes under salt stress. Environmental and Experimental Botany, v.49, p.107-120, 2003. https://doi.org/10.1016/S0098-8472(02)00064-3

LEONARDO, M.; BROETTO, F.; VILAS-BÔAS, R. L.; ALMEIDA, R. S.; GODOY, L. J. G.; MARCHESE, J. A. Estresse salino induzido em plantas de pimentão e seus efeitos na produção de frutos. Horticultura Brasileira, v.21, p.1-4, 2003.

LIMA, G. S.; NOBRE, R. G.; GHEYI, H. R.; SOARES, L. A. A.; SILVA, A. O. Cultivo da mamoneira sob estresse salino e adubação nitrogenada. Revista Engenharia Agrícola, v.34, 2014.

NASCIMENTO, M. V.; SILVA JUNIOR, R. L.; FERNANDES, L. R.; XAVIER, R. C.; BENETT, K. S. S.; SELEGUINI, A.; BENETT, C. G. S. Manejo da adubação nitrogenada nas culturas de alface, repolho e salsa. Revista de Agricultura Neotropical, v.4, n.1, p.65-71, 2017a. https://doi.org/10.32404/rean.v4i1.1099

NASCIMENTO, P. dos S.; PAZ, V. P. da S.; FRAGA JÚNIOR, L. S.; COSTA, I. P. Crescimento vegetativo do quiabeiro em função da salinidade da água de irrigação e da adubação nitrogenada. Colloquium Agrariae, v.13, n.1, p.10-15, 2017 b.

NOBRE, R. G.; GHEYI, H. R.; CORREIA, K. G.; SOARES, F. A. L.; ANDRADE, L. O. de. Crescimento e floração do girassol sob estresse salino e adubação nitrogenada. Revista Ciência Agronômica, v.41, p.358-367, 2010.

NOBRE, R. G.; LIMA, G. S.; GHEYI, H. R.; SOARES, L. A. ANJOS.; SILVA, A. O. Crescimento, consumo e eficiência do uso da água pela mamoneira sob estresse salino e nitrogênio. Revista Caatinga, v.27, n.2, p.148-158, 2014.

OLIVEIRA, A. M.; OLIVEIRA, A. M. P.; DIAS, N. S.; MEDEIROS, J. F. Irrigação com água salina no crescimento inicial de três cultivares de algodão. Revista Irriga, v.13, n.4, p.467-475. 2008.

PEDRO, A. A.; STEINER, F.; ZUFFO, A. M.; DOURADINHO, G. Z.; OLIVEIRA, C. P. Crescimento inicial de cultivares de algodoeiro submetido ao estresse salino. Revista de $\begin{array}{lllll}\text { Agricultura } & \text { Neotropical, } & \text { v.3, } & \text { n.4, } & \text { p.32-38, }\end{array}$ https://doi.org/10.32404/rean.v3i4.1183

PEREIRA, J. R.; ARAÚJO, W. P.; FERREIRA, M. M. M.; LIMA, F. V.; ARAÚJO, V. L.; SILVA, M. N. B. Doses de esterco bovino nas características agronômicas e de fibras do algodoeiro herbáceo BRS Rubi. Revista Agro@mbiente, v.6, n.3, p.195-204, 2012. 
SÁ, F. V. da S.; BRITO, M. E. B.; MELO, A. S.; ANTONIO NETO, P.; FERNANDES, P. D.; FERREIRA, I. B. Produção de mudas de mamoeiro irrigadas com água salina. Revista Brasileira de Engenharia Agrícola e Ambiental, v.17, n.10, p.1047-1054, 2013.

SANTOS, J. B.; GHEYI, H. R.; XAVIER, D. A.; CAVALCANTE, L. F.; CENTENO, C. R. M. Crescimento do algodoeiro sob salinidade da água de irrigação e adubação nitrogenada. In: INOVAGRI INTERNATIONAL MEETING, 2., 2014, Fortaleza. Anais[...] Fortaleza: INOVAGRI, 2014. p. 1625-1634.

SOUZA, L. de P.; LIMA, G. S. de.; GHEYI, H. R.; NOBRE, R. G.; SOARES, L. A. dos A. Emergence, growth, and production of colored cotton subjected to salt stress and organic fertilization. Revista Caatinga, v.31, n.3, p.719-729, 2018. http://dx.doi.org/10.1590/1983-21252018v31n322rc

TAIZ, L.; ZEIGER, E. Fisiologia vegetal. 3. ed. Porto Alegre: Artmed, 2009. 812p.

YONG, J. W. H.; NG, Y. F.; TAN, S. N.; CHEW, A. Y. L. Effect of fertilizer application on photosynthesis and oil yield of Jatropha curcas L. Photosynthetica, v.48, n.2, p.208-218, 2010. https://doi.org/10.1007/s11099-010-0026-3 